\title{
THE MEANING OF WORDS AND HOW THEY RELATE TO THE ONGOING TEXT:A STUDY OF SEMANTIC COMMENTS MADE BY TWO 7-YEAR-OLD SCHOOLCHILDREN ${ }^{1}$
}

\author{
Eduardo CALIL*
}

- ABSTRACT: This study aims to analyze the semantic comments made by a dyad of newly literate students (6 to 8 years), during writing processes in real time. Affiliated to the field of studies proposed by the Textual Genetics, from an enunciative approach, we treat as a unit of analysis the Dialogical Text (DT) established in face-to-face interaction, respecting their multimodal dimension (gestures, expressions, body movements) and spontaneous speech and co-enunciation of the students in pairs. The DT constitutes the recognition by one of the speakers of Textual Objects (TO) and comments related to these objects. The relationship between the TO and recognized semantic comments is defined as a type of Commented Oral Erasure (COE). Our analysis was based on a data set composed by the filmic record of 16 writing process stories invented by the same dyad of students. We discussed the occurrence of this type of COE in 3 writing processes. Our results indicate that the semantic comments directed to OT aimed at the establishment of textual unit, indicating how the students were thinking about this problem for the manuscript in progress. The relationship between the TO and uttered semantic comments mapped the genesis and the textual creation process. Moreover, the semantic COE show the students' linguistic and textual knowledge that are not possible to identify in the finished manuscript.

- KEYWORDS: Classroom. Textual production. Dialogue. Writing. Authorship. Manuscript. Erasure.

\section{Introduction}

Since the 1980s, Textual Genetics ${ }^{2}$ (TG) studies, which researchers interested in investigating the process of literary creation had initiated a decade earlier, have sought to understand the genetic journey of writings produced in a school context by beginner writers. The works of Claudine Fabre (FABRE, 1990, 2002), who saved from the

\footnotetext{
* CNPq (processo304050/2015-6). UFAL - Federal University of Alagoas. Centre of Education. Maceió - AL - Brazil. 57044098 - eduardocalil@icloud.com

Translated by A. Caram (adcaram@gmail.com). Revised by B. Allain (beatrice.tradutora@gmail.com)

2 The wide scope of this study may be considered at $<$ http://www.item.ens.fr $>$.
} 
"wastebasket" drafts ${ }^{3}$ produced in the classroom, influenced a large number of studies (PENLOUP, 1994; BORÉ, 2000; ALCORTA, 2001; PLANE, 2006; DOQUET, 2011; CALIL, 2009) aimed at understanding the reflective activities and metalinguistic operations that occur during the writing of a text ${ }^{4}$.

Based on different products written by students (draft, manuscript, copy, recopy, early version), several textual elements were identified that point to the recursive relationship of the writer with his own text. These studies show that erasures made on the same product (a student's draft or manuscript), or modifications from one version to another, indicate the writer's returns over what was written. Whatever the manuscript may be, the vast majority of TG studies focus on identifying and describing what was altered, corrected or suppressed from the written product. Many of these studies identify and describe the four types of erasures (erasing, adding, substituting and rearranging), quantifying the graphic and linguistic modifications made during the writing process. Fabre (1990) showed, and subsequent studies confirmed, that numerous erasures are found even in manuscripts written by newly literate students (6- to 9-years-old), indicating that metalinguistic operations occur at different linguistic levels (graphic, orthographic, lexical, semantic, syntactic, and punctuational).

Among these operations, those involving the writer's lexical choices are very important to understand the author's text creation and his metalinguistic and metatextual reflections while writing. However, although it is useful to identify and describe erasures and lexical substitutions in order to reconstitute the writing process, access to the student's mindset while he was writing is limited to the marks he left on the paper he handed to the teacher. The erasures the writer makes indicate the procedural and recursive character of metalinguistic operations in the ongoing text, but the analysis of these marks only allows for a posteriori or after-the-fact interpretations of the process.

One of the few studies that sought to analyze the metalinguistic operations performed during the writing process in real time was developed by Doquet (2011). The French researcher used the program Genèse du Texte ${ }^{5}$ to simultaneously capture the movements of cursor, keyboard and mouse. Her study, which involved 10-year-old students writing without the teacher's interference, reproduced online the temporal dimension of the erasures made during the writing process. This accurate and precise chronological record, which captured the timing of the cursor movements on the computer screen and of the keys that were touched, revealed the pauses the writer made between one movement and the next.

Unlike the offline analyses of textual products (school manuscripts) conducted after the fact, the information provided by the Genèse $d u$ Texte program indicates

This term, recurring in many French studies, refers to the text written by the student as "draft". As stated in Calil (2008, p.24), we feel it is more appropriate to refer to this type of work as "school manuscript".

4 The reader may verify the emphasis given to the French student's "draft" (brouillon) in some issues of the periodicals Pratiques, Le Français Aujourd'hui, Linx, E.L.A.

5 Available in: <http://www.lecture.org/ressources/index_ecriture.html>. Access in: 03 Nov. 2016. 
that there was a longer or shorter pause between one word and the next, and that the cursor was moved to the next line and then returned to its starting position. This gives rise to numerous hypotheses regarding the pauses and the modifications observed, or even to ascribe intentions to the writer about what he may have thought while choosing one word rather than another, or when he made a pause that was longer than another.

The correlation between erasures and pauses introduced a new component into the analysis of text creation. Among the various erasures that Doquet analyzed, she identified the time and the pauses involved in lexical substitutions and deletions. For example, she showed that the student wrote "se débrouillaient" and "se défendaient" a few seconds before writing the pronominal verb "se cachaient" (DOQUET, 2008, 2011). However, despite the chronological precision with which the erasure was recorded, it was not still possible to obtain evidence of why the student made these substitutions. In her analysis of these substitutions, the researcher interprets what happened by stating "sans doute la pause qui suit [se cachaient] marque-t-elle un doute, une hésitation" (DOQUET, 2011, p.155, emphasis added). However, how can one know what happened during the pause? What was the writer's doubt? What exactly does the hesitation correspond to? There is no way of knowing. It is not possible to assert whether a doubt did, in fact, occur.

In our studies (CALIL, 2003, 2008, 2012a, 2012b, 2013) we have proposed a methodology using multimodal resources to record the ongoing manuscript, while respecting the environmental, didactic and interactive conditions of the classroom. Focusing on textual production practices adopted by schools that follow a "socioconstructivist" curricular approach, we opted for collaborative textual production (paired writing of the same text) as the didactic-methodological procedure, which would give us access to what students think while they write. Using audiovisual instruments, we video-recorded the dyadic interactions between a pair of students. Starting from the dialog between them - characterized by spontaneous speech, gestures and facial expressions - and its relationship with the ongoing manuscript, we were able to identify textual objects the students recognized during the writing process, as well as their comments about these objects while considering whether to maintain, modify or erase them. These comments made during the process generate effects in the configuration of the final product, revealing the linguistic, graphic and discursive elements that were not written or were written and then erased.

Our intention in this paper is to demonstrate that certain words may be recognized as textual objects, and this is followed by remarks that express the students' reflections about their meaning and their relationship with the ongoing manuscript. 


\section{Writing and Dialogue}

Studies that analyze dialogues that take place during dyadic writing ${ }^{6}$ tend to emphasize the interactive (DAIUTE; DALTON, 1993; VASS, 2007), conversational (GAULMYN, 1994; BOUCHARD; GAULMYN, 1997) or learning (SWAIN; LAPKIN, 2002; STORCH, 1999) aspects more than the writing and genetic dimensions of the text being written. Unlike Textual Genetics studies, researchers who analyze "conversational writing" (GAULMYN, 1994; BOUCHARD; GAULMYN, 1997) consider collaborative textual production as an intensive task of "reformulation" (GAULMYN, 2001), using as the object of study the "oral-text" comprised of "metadiscourses" (BOUCHARD, 1997) aimed at the "target-text" (APOTHELOZ, 2005). The studies published in the books organized by Gaulmyn, Bouchard and Rabatel, (2001) and by Bouchard and Mondada (2005) examine the conversational writing of two non-francophone university students while they write an argumentative text about "school homework."

Although it is not possible to pinpoint precisely the relationship between the dyad's dialogue and the moment something is being written on the sheet of paper, Apotheloz $(2001,2004,2005)$ discusses what he called an "autonymic event." These events are associated with the moments when two university students, employing their own linguistic skills and international standards, formulate and eventually evaluate the syntagmas that will enable the text to advance toward its final form. According to the author, some forms of evaluation may be recognized in dialogues, such as:

409 H: la polémique du devoir... à la Maison

[409 H: the polemics of duty... at home]

$410 \mathrm{~F}$ : 'polémique' qu'est que ça veut dire

[410 F: 'polemics' what does it mean]

$411 \mathrm{H}$ : La 'polémique' c'est: la grande discussion. Polémique c'est la discussion.

[411 H : the 'polemics' is the great discussion. Polemics is the discussion.]

$412 \mathrm{~F}$ : Ah, oui.

[412 F: Oh, yes.]

Turn 411 by $\mathrm{H}$ has an "enoncé de double categorization?." This statement contains simultaneously "le sens d'un mot de la langue (définition de mot)" "and the "objet désigné génériquement (definition d'objet)" (APOTHELOZ, 2001, p. 53). The emphasis given to the "conversational" aspect, to the description of the "patterns

\footnotetext{
6 Collaborative writing situations involving more than 2 participants in school settings have also been the subject of many studies (DALE, 1994; CAMPS et al., 1997, ROJAS-DROMOND; ALBARRAN; LITTLETON, 2008; CRINON, 2012, among many other studies). Here our focus will be on studies that focus only on dyadic writing processes.

Statement with two categories.

The meaning of a word in the language (definition of the word).

Object designated generically (definition of the object).
} 
de reformulation"10" (APOTHELOZ, 2005) and to the "syntaxe de l'expansion" (APOTHELOZ, 2001) does not value this form of metalinguistic reflection. However, they play an important role in the construction of the "target-text" and its final form. On the one hand, in collaborative writing situations, statements of this kind are preceded by the return of one of the participants to a spoken term to be written ("polémique' qu'est que ça veut dire", 410 F). On the other hand, in this example there is a metalinguistic operation indicating an autonymic reflection ("la "polémique' c'est: la grande discussion. Polémique c'est la discussion." $411 \mathrm{H}$ ) that seeks to justify what is being written in the ongoing text.

From our genetic standpoint, whose object of study is the dyadic writing of two newly literate students, the relationship between these two aspects (recursiveness and metalinguistic reflection) is of primary importance. Reconsidering a previously spoken term indicates recognition of its importance to the ongoing text and what the writer says about it expresses explicitly what he knows and thinks about this term, and in particular, suggests the relationship the writer assigns to its relevance (or not) to what is being written. The interrelatedness between these aspects is characterized as "tension points" (CALIL, 1998, p.97) in the process of paired writing. Analyzing their occurrence may indicate what the writer thought while making an erasure, an aspect that cannot be revealed by the end product (manuscript) or the time record (pauses).

\section{Erasure and Oral Erasure}

Tension points indicate recursive actions by the students while working on the manuscript. The record of their dialogue about what they were going to write or about what they had already written reveals what they were thinking regarding certain textual objects ${ }^{12}$, about the way the text was being arranged, and about the genesis of the creative process. These tension points identified in the dialogical flow led to metalinguistic operations, whose rules are similar to those interpreted from the graphic erasures that are visible in the text. We called these tension points in the dialogical flow “oral erasures" (CALIL, 1998, p.108).

According to Calil (2012a, 2012b, 2013), Calil and Felipeto (2012) and Felipeto (2008), in collaborative or paired writing, the oral erasure, identified from the association and synchronization between an ongoing manuscript and its final version, is a powerful co-enunciative phenomenon to map and understand the pathways of creative and writing processes, even though the spoken elements are not always included in the end product. If the written erasure, in essence, indicates an alteration or change in what has already

10 Reformulation patterns.

11 Expansion syntax.

12 Our understanding is that the term "textual object" is more suitable to our purpose than the term "objets de discours" (MONDADA, 1994). Textual object refers to a graphic, linguistic or discursive element directly related to the on going text and considered by the writer as an element that may be added or altered. 
been written, characterized by the writer's more or less complex return to a given point of the ongoing manuscript, we argue that the returns that are manifested verbally during the dialogical flow, when focusing on what will or will not be inscribed ${ }^{13}$ and linearized $^{14}$, should also be treated as a form of manifestation of the erasure. It is an erasure whose provenance stems from its oral, dialogical and co-enunciative nature, but whose effect interferes in the final form of the manuscript.

The oral erasure, characterized co-enunciatively during collaborative writing, preserves the spontaneous and shared utterances. Established during the writing process, it indicates the spontaneous and unpredictable way in which each student modifies elements to be written into the ongoing manuscript. Thus, the record of oral erasures outlines the creation of the paired writing process.

Within the Dialogical Text (DT) established between the students, we identified the recognition of "textual objects" by one of the speakers. This identification considered how the speaker treated a Textual Object (TO), altering it with respect to what had already been written, or reformulating ${ }^{15}$ it so that it could be inserted into the ongoing manuscript. In the aforementioned oral erasure, this identification is characterized by an interruption the speaker makes in the narrative and written flow, a "return" to the identified TO, followed by comments about it.

The TOs extracted from the DT and associated with the ongoing manuscript stand out through the voice of each speaker/writer, in the exact instant they are spoken, in a real, everyday and immediate situation. Added to these aspects are the immediate context and the production conditions - given socio-historically and didactically which are the idiosyncratic expressive elements of each of the participants (body movement, gestures, looks, facial expressions, holding and positioning of the pen),

13 We preferusing the term "to inscribe" instead of "to write" due to its more graphic and less linguistic connotation. This allows us to use it to refer to graphic marks which are not necessarily linguistic. For example, pupils sometimes consider aspects of the graphical form of a grapheme or of the physical space available on the paper, commenting on the number of lines remaining to finish the story. They may also comment on the small amount of room to enter a long title, trying to reshape the latter to fit into the limited space.

14 The movement from the "plan of ideas" to the "plan of the written text" is called, in the specialized literature, as "translating" (HAYES; FLOWER, 1980) or "text-generation" and "transcription" (BERNINGER et al., 1994). For us, interested in understanding the multimodal and ecological dynamics of on going text creation, it is important to consider this moment of the writing process by newly literate children as being composed of two movements, inscription and linearization. One is the "inscription" of the mark on the paper, including both the linguistic and nonlinguistic graphic marks (tracings, erasures, visual aspects of the sheet). Secondly, there is "linearization", that is, the spatial alignment of the text on the sheet, resulting from the syntagmatic association between letters, words, phrases and paragraphs, shown both sequentially and linearly. In order to linearize it is necessary to inscribe sequentially the graphic forms on to the sheet. On the other hand, inscribing a graphic form on to the text can occur with out necessarily involving linearizing.

15 The reformulation that occurs during collaborative writing is a phenomenon studied by Milian (2005). Her assumption is that "It allows the writer(s) to operate on the text online, following a reflective process with different degrees of awareness, and guided by her/their own knowledge and goals" (MILIAN, 2005, p.338). In our studies, we seek to reformulate the point of view of Textual Genesis. This means that we will consider both metalinguistic reflections expressed by the student, as the relationship between what he commented orally on the Textual Object, and, concurrently, how the TO was effectively inscribed and/or linearized in the on going manuscript. This perspective of ours, just described, is missing in most studies of the "reformulations" performed by students during the collaborative writing process. 
face-to-face interaction, and their involvement in the shared and collaborative writing. And lastly, the spontaneous, unplanned, unpremeditated and unpredictable nature of the oral erasures is another aspect equivalent to the occurrence of written erasures. As studies on Genetic Criticism (BIASI, 1996; GRESILON, 1994) have shown, it is impossible to predict, anticipate or plan when an erasure will occur or be produced. An erasure is recognized only after identifying at which point in the process there was a return, which may or may not have left identifiable graphic marks upon the product.

The recognition of textual objects in a DT established during collaborative writing may be followed by comments ${ }^{16}$ about these objects. The correlation between the textual objects and comments would represent forms of manifestation of the oral erasure. Among the various forms of commentary identified (CALIL, in press), we will discuss those related to the considerations about the meaning of words and their relationship with the manuscript in progress. From the linguistic and enunciative standpoint, these comments present expanded syntactic structures, such as:

- X because of Y

- $\mathrm{X}$ otherwise $\mathrm{Y}$

- $\mathrm{X}$, but it must have $\mathrm{Y}$

- $\mathrm{X}$, seems that $\mathrm{Y}$

- $\mathrm{X}$, that is, $\mathrm{Y}$

- $\mathrm{X}$, but this way it becomes $\mathrm{Y}$

- X, meaning, Y

- $\mathrm{X}$, this means $\mathrm{Y}$

- $\mathrm{X}$, they will think Y

- Etc.

These forms of expression of oral erasures are therefore characterized based on the identification of the TO chosen by the pupil and its relationship with the proffered comment(s). Even if the oral erasure does not produce a visible or identifiable alteration in the end product, it clearly describes the text creation and how the pupils are envisioning the manuscript in progress. Because we consider the resulting comments as a dialogical and co-enunciative phenomenon inherent to the dyadic writing process, we will now describe and analyze some occurrences of oral erasures and their effects onto the ongoing manuscript.

16 It is worth highlighting that studies such as David (2001) and Morin (2005) analyze metalinguistic "comments" (metagraphic and meta-orthographic) made by schoolchildren. David looks at the comments from beginner writers made during the review of a text previously produced; Morin discusses the comments made by children about the production of words. These situations are distinguished, as we shall see, from the interactional dynamics (co-enunciation) of comments in real time, made during the moment in which a manuscript is being produced for the first time. 


\section{Context and proposals for paired text production}

In order to identify and describe the aforementioned oral erasures, we have used material collected over a two-year period when two newly literate girls (Isabel and Nara, between 6 and 8 years of age) participated in the filming of 16 processes of collaborative writing of fictional stories ${ }^{17}$. The teachers consistently employed the same didactic strategies when presenting the proposals for text production:

$1^{\text {st }}$ moment (presentation): presentation of the assignment, establishment of the dyads, selection of which pupil will write and which will dictate.

$2^{\text {nd }}$ moment (joint creation): the dyads (before receiving paper and pen) outline the plot and agree about the story they are going to write.

$3^{\text {rd }}$ moment (inscribing and linearization): starts when the pupils tell the teacher they have already agreed on the story and are given paper and pen to begin writing. This moment is characterized by the recording of the manuscript in progress, when each mark on the paper is made, each letter, word, phrase, title... Here, inscribing means making ink marks on the paper, while linearization refers to the written syntactic threads and positioning of each graphic-linguistic element in a particular sequence (whether accompanied or not by commentary) on the lines of the paper.

$4^{\text {th }}$ moment (reading and revision): after they have finished writing the story, the children inform the teacher, who may ask the pair to read the story to her, and make changes they may deem necessary.

The examples analyzed below show the occurrence of oral erasures during the $3^{\text {rd }}$ moment (inscribing and linearization), when students have pen in hand and sheet of paper on the table.

\section{Recognized words and semantic comments pertaining to them}

Our discussion of oral erasures refers to the recognition of words or expressions enunciated by one of the speakers, followed by different comments about their meaning. We will analyze three dialogical texts selected from three different writing processes, examining the conversation that followed the recognition of the word, as well as the metalinguistic reflection pertaining to it and to the ongoing manuscript.

17 Currently, our collection, kept at the Laboratório do Manuscrito Escolar (LAME), contains a variety of recorded material collected at Brazilian, French and Portuguese schools. The corpus studied in this work is part of the "Dossiê Vila", established between 1991 and 1992. 


\section{Abcdefghijklmnopqrstuvz vs. Alphabetic Order}

In our material we found frequent occurrences of the selection of textual objects pertaining to the words to be written. When tension points arise about the inclusion or writing of one term or another, the speakers may make different types of comments to defend their ideas or intentions. These comments may present arguments related to different values involving situational, interactive or communication conditions, to the meaning of the words and expressions themselves, and to the ongoing manuscript.

In the DT below, note the occurrence of two types of arguments pertaining to comments about two TOs that are competing for the same position in the ongoing manuscript.

Figure $1^{18}$ - Status of the school manuscript “The Gluttonous Queen", lines 1 to 5, after the word "alphabetic" was inscribed, at 08:29 ( $3^{\text {rd }}$ process, 06/27/1991).

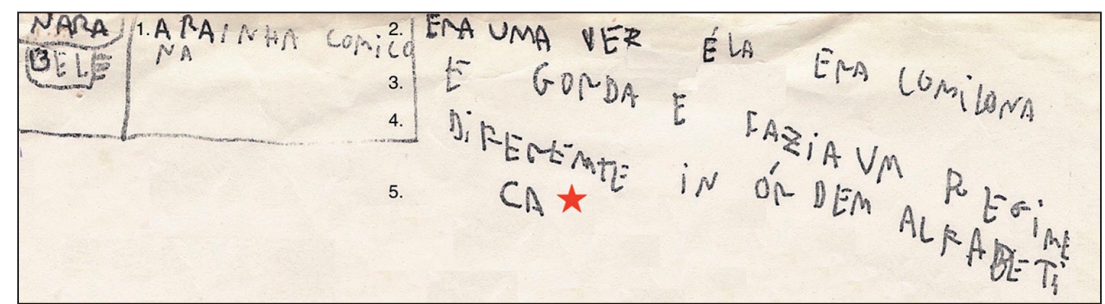

Source: School Manuscript Laboratory.

DT 3rd process (manuscript “The Gluttonous Queen”), 07:01 - 08:2919.

55. NARA: (Isabel is writing "e fazia um regime / and was on a diet" (line 4). Nara turning to her) And one day the Qu...

18 Here is the literal transcript of this manuscript:

1. A rainha comilona / The Gluttonous Queen

2. Era uma vez uma rainha. Ela era comilona/ Once upon a time a Queen. She was gluttonous

3. e gorda e fazia um regime / and fat and was on a diet

4. is diferente em ordem alfabéti / is in adifferent alphabe order

5. $\mathrm{ca} / \mathrm{tic}$

19 This way of identifying the Dialogal Text shows the number of a process recorded long the two years (3rd process), and the beginning and ending times of this particular fragment of dialogue between the children. The standard followed in this corpus, is that time is measured from the moment the video-recorder is turned on as soon as the teacher initiates the presentation of the assignment. The purpose of timing the exercise is two fold. First, to indicate the precise moment in the dialogue when the DT happened, facilitating its identification in the video. The second objective is to indicate to the reader the duration of the DT that is related to the point shown by the star on the manuscript. On the DT transcript we indicate who was writing with an asterisk (*), and what was being inscribed and linearized during a particular turn is shown between brackets. Finally, the TO is shown in red, and the comments related to it are in blue. 
56. ISABEL*: (Finishing writing "regime/diet"). Wait a little, Narinha. (Upon finishing inscribing "regime", moving pen away from the paper and turning to Nara). No. But let's do it this way... in alphabetic order... because 'alphabetic' is 'abcdef'.

57. NARA: OK. I know. (Isabel going back to writing) And ate in order...

58. ISABEL*: (Reading the last word written) ...diet... different... (Starting to inscribe [DIFEREMTE], on line 5).

59. NARA: ... in alphabetic order (Isabel finishing inscribing [DIFEREMTE]) Then one day with ' $b$ '... (Looking at the alphabet hanging above the blackboard) 'a', 'b', 'c'...

60. ISABEL*: (Ceasing to write). Wait a little. No. (Looking at Nara, gesticulating and speaking rapidly) I'm not going to write 'abcde...' uuuuu.... in or... in alphabetic order. (Turning back to the text and reading) ...different diet...

61. NARA: (In a complaining tone) I dictate, right, Bel, ôô...

62. ISABEL*: Wait a moment, Narinha. (Brief pause) Because... it looks strange, doesn't it? (Quickly singing the whole alphabet) abcdefghijklmnopqrstuvz...

63. NARA: She ate in alphabetic order... and then going to say... (Gesticuling as if about to sing the alphabet)

64. ISABEL*: In alphabetic order. (Going back to writing 'in order' [IN ÓRDEM]. ...order. That's not what we agreed... ...phabetic. (Inscribing [ALFABÉ]. Stops inscribing and turns to Nara) You know, Narinha, that's not what we agreed. We didn't agree. We didn't agree this way...

65. NARA: Yes... you didn't tell that we were going to do in 'alphabetic order' either, and I said OK.

66. ISABEL*: ...alphabetic. (Turning to the end of line 4, inscribing 'ti' [TI] and changing to another line (line 5), inscribing 'ca' [CA]). ...in alphabetic order. (Stops inscribing and turns to Nara asking her to continue to dictate) Go ahead.

The two TOs highlighted in red (Nara's turns 55 and 59) indicate how the story should proceed after writing "and was on a diet" (e fazia um regime, line 3 ). The first TO occurs when Nara is dictating "and one day the Qu..." (e um dia a ra...). Isabel, who was finishing inscribing the word "diet," still needed to write a line about the gluttonous queen's diet. During the moment of "joint creation," they had agreed that the Queen was on a diet in which she "first ate something starting with 'a,' then ate everything starting with 'b'..." (comia uma vez uma coisa com ' $a$ ', depois comia tudo que começa com ' $b$ '... turn 14, Isabel). To prevent the story from continuing the way Nara dictated it, Isabel (turn 56) says, for the first time during this writing process, "in alphabetical order." Right after this reformulation, she explains and at the same time justifies "because 'alphabetical' is abcdef" (porque 'alfabética'é abcdef). This autonymic comment recognizes the expression "abcdef" and mentions the word 'alphabetical,' indicating a metalinguistic knowledge acquired in the current school 
situation (the concept of "alphabetical order"). The comment also indicates the child's metatextual ability to express this information in the ongoing manuscript.

Nara accepts the inclusion of "alphabetical order" (ordem alfabética, turn 57), but returns to the story starting from: "Then one day with 'b'... 'a', 'b', 'c'..." (Dai um dia com ' $b$ '... ' $a$ ', ' $b$ ', ' $c$ '...', turn 59), looking at the letters of the alphabet hanging above the blackboard. Her utterance leads to the recognition of another TO ([regime/ diet] with 'a', 'b', 'c'), which also will be rejected by Isabel, this time accompanied by comments presented in three successive turns (turns 60,62 and 64).

Turns 60 and 64 present comments containing pragmatic arguments. In 60, Isabel uses the authority afforded her by the pen and says: "I'm not going to write abcde..." (eu não vou escrever abcde...). Later, in turn 64, she resorts to another pragmatic argument: "That's not what we agreed" (a gente não combinou assim). Here, the argument highlights not only the teacher's instructions about the assignment (to create the story together and then write down what was agreed) but also what the girls agreed about as they were creating the story together. Again, this comment has a pragmatic value because it pertains to the contextual aspects (interactive and communicative) of the activity. As is typical of such comments, which are identified in several other instances in our data set, the pragmatic argument aimed at preventing the inclusion of a textual object does not involve linguistic or textual aspects of the ongoing story. In her defense of the proposed TO (turn 65), Nara also uses a pragmatic argument, repeating what Isabel said and adding “....and I said OK” (e eu falei que tá).

Between one pragmatic comment and another, Isabel says “.... it looks strange, doesn't it? ...abcdefghijklmnopqrstuvz..." (fica estranho, né? ... abcdefghijklmnopqrstuvz...) (turn 62). This is the utterance we are interested in observing. This new comment adds argumentative strength to the earlier one "because 'alphabetic order' is abcdef" (porque 'ordem alfabética'é abcdef) in turn 56. At the moment it is uttered in turn 62, her comment has a semantic-textual argumentative value. Isabel's reflection expresses awareness of the consistency of the text and indicates her position as reader of what is being written. At this moment, Nara does not appear to be concerned about achieving this consistency.

The two comments formulated with semantic arguments, "No. But let's do it this way... in alphabetical order... because 'alphabetical' is 'abcdef'" (turn 56) and "Because... it looks strange, doesn't it? ...abcdefghijklmnopqrstuvz..." (turn 62 ), are complementary and interrelated. On the one hand, they indicate Isabel has established a synonymic and conceptual relationship between "alphabetical order" and "abcdefghijklmnopqrstuvz," and on the other, that she has assumed the role of a reader, who is disagreeing with the possible insertion of "abcdefghijklmnopqrstuvz..." in the ongoing manuscript ("it looks strange, doesn'it"). There is no written erasure on paper which would indicate "abcdefghijklmnopqrstuvz" was erased and substituted for "alphabetical order" (it could certainly have happened), but the presence of the oral erasure at this point in the manuscript is evidence of why the children wrote "alphabetical order" instead of a different term. The oral erasure has a stronger explanatory value 
than the mere identification of a possible written erasure in the end product, or even of access to the long pause between the record of the word "diet" (regime) and of the syntagma "in alphabetical order." If all we had in hand was the manuscript with the substitution erasure between "abcdefghijklmnopqrstuvz" and "alphabetical order," several assumptions could be made about why the writer replaced one with the other, but none of them would be based on what really happened when the erasure was made, or on what the writer was thinking while making it.

The explanatory dimension of the analysis of the pupils' dialogue and its relationship with the end product lies in the fact that it reveals not only the text creation but also how the writers are considering several TOs at that particular moment in the process. The dialogue, accompanied by the video-recorded facial and gestural movements and body language, and by the mark of the pen on paper, is part of what we call "verbal manuscript," which preserves the memory of each process and the record of all its directions and recursive movements in real time. Through the utterances, we also gain access to the subjective differences between the writers, to their individual linguistic and textual knowledge, and to the relationships they have established with the textual objects recognized as challenging during the writing process.

\section{Sad vs. Solitary}

Our corpus contains occurrences of oral erasures in which the TO triggers comments involving other arguments of semantic value, expressing the meaning a word has for the speaker or its meaning in relation to the words surrounding it. In the 16 processes there are several occurrences of comments with this type of argument, such as one that emerged when the children were about to write the word "sad" (triste) on line 12 of the manuscript "The three Todinhos ${ }^{20}$ and the Flavor Lady" (Os três Todinhos e a Dona Sabor).

Figure $\mathbf{2}^{\mathbf{2 1}}$ - Status of the school manuscript "The three Todinhos and the Flavor Lady," lines 10 to 12 , at 25:51 ( $6^{\text {th }}$ process, 11/28/1991).

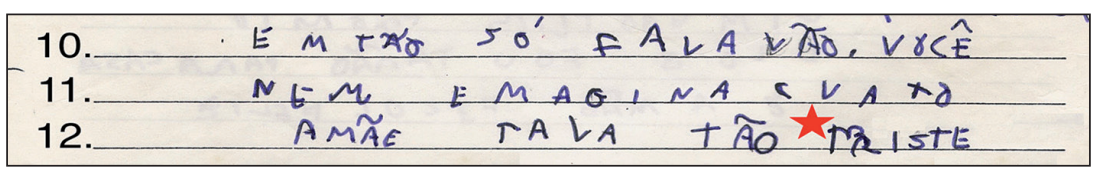

Source: School Manuscript Laboratory.

20 In Brazil, Toddynho is a very famous chocolate milk consumed by children. It is a product of the brand Toddy, manufactured by PepsiCo. In the invented story that received this title, the students made an association between the "three little Pigs" ("os três Porquinhos", in Portuguese) and the name of the chocolate milk.

21 Literal transcript:

10. Então só falavam. Você / So [they would] only speak you

11. nem imagina quanto / can't even imagine how much

12. A mãe tava tão triste/The mother was so it sad 
DT_ $6^{\text {th }}$ process (manuscript "The three Todinhos and the Flavor Lady / Os três Todinhos e a Dona Sabor"), 25:00 - 25:51.

198. ISABEL*: (Reading out loud 'so all they said') ...So all they said. (Inscribing the period after 'said' [FALAVAO].) Period. (Inflecting her voice and reading 'you can't even'.) You can't even... (Inscribing 'imagine how much') imagine... i $[\mathrm{E}] \ldots$ ma $[\mathrm{MA}] \ldots$ gi $[\mathrm{GI}] \ldots$ ne[NA] ... (Inscribing 'how much' [CUATO]. Finishing writing 'how much', and turning to Nara abruptly) Suddenly... No. The mother was... was very sad, right? But there was lots of crying... (Gesticulating as if she is the character.) ...suddenly a fairy showed up... then they got scared, right? ...a fairy showed up, right ?

199. NARA: They had never seen a fairy.

200. ISABEL*: (Inscribing'the mother'.) ...the mother... the mother [A MÃE]... (Inscribing and inflecting her voice.) ...was so solitary. (Inscribing 'was so' [TAVA TÃO].)

201. NARA: (Asking emphatically.) Solitary?

202. ISABEL*: No. was... No. was... 'Solitary' means 'alone', so it has nothing to do with. (Inscribing 'sad'.) She was... was... so sad [TRISTE]... that her children said only...

Like the earlier manuscript, this one also has no erasure to indicate the substitution of the word "solitary" for "sad," written on line 12 at the end of the phrase "the mother was so sad / a mãe tava tão triste." "Triste" is written as if there were no competition with other words. However, when the pupils were writing this part of the story, "sad / triste" was considered synonymous with "solitary / solitária," accompanied by semantic and textual comments.

Initially, Isabel says the mother "was very sad" (turn 198). At the moment she is inscribing and aligning the phrase "the mother was so sad" (turn 200), Isabel utters "solitary" in place of "sad": "...the mother... the mother [A MÃE]... (Inscribing and inflecting her voice.) ...was so solitary." In this exact moment, the word "solitary" is recognized by Nara as a TO, distinguishing it from the flow of speech and narrative sequence of the story.

The unexpected inclusion of the word "solitary" instead of "sad" would have been written and remained unnoticed had Nara not found it strange and interrupted the process. Her questioning and enunciative return to the word "solitary," in turn 201, leads Isabel to reflect on its meaning and evaluate its pertinence to the ongoing story.

This takes place as follows. In turn 202, in response to Nara's questioning, Isabel repeats the word and then comments about it, using two related arguments. First she makes a metalinguistic autonymic analysis, ${ }^{22}$ explaining the meaning of "solitary": "solitary means alone," a reflection very similar to the one described previously: "I am

22 We analyze an other example of this kind of semantic comment in Calil (2012a). 
not going to write 'abcdef.' I'm going to write 'alphabetical order,' because 'alphabetical' [order] is abcdef."

The second argument has a textual value, similar to the earlier utterance "it looks strange, doesn't it? ...abcdefghijklmnopqrstuvz..." Isabel, still in turn 202, orally erases the inclusion of the word "solitary" in the ongoing manuscript by saying, "so, it has nothing to do" with the story.

The semantic and textual argument in this comment prevents the word "solitary" from being included in the ongoing manuscript. Despite its synonymic and associative relationship with "sad," this TO causes a departure from the narrative content established up to this point: the story narrated that the children just talked, they talked a lot, and the mother was sad (not solitary) because of it.

\section{Entrance vs. Door vs. Hole}

This last example of a semantic comment was done by Nara, who makes this type of comment less often than Isabel. However, the fact that Nara begins to use this type of comments, which were absent in her turns up to this $8^{\text {th }}$ writing process, indicates that Isabel's semantic comments have somehow influenced Nara's way of thinking about the ongoing manuscript. 
Figure $3^{23}$ - Final status of the school manuscript "The Magic

Closet / O guarda-roupa mágico" ( $8^{\text {th }}$ process, 04/02/1992).

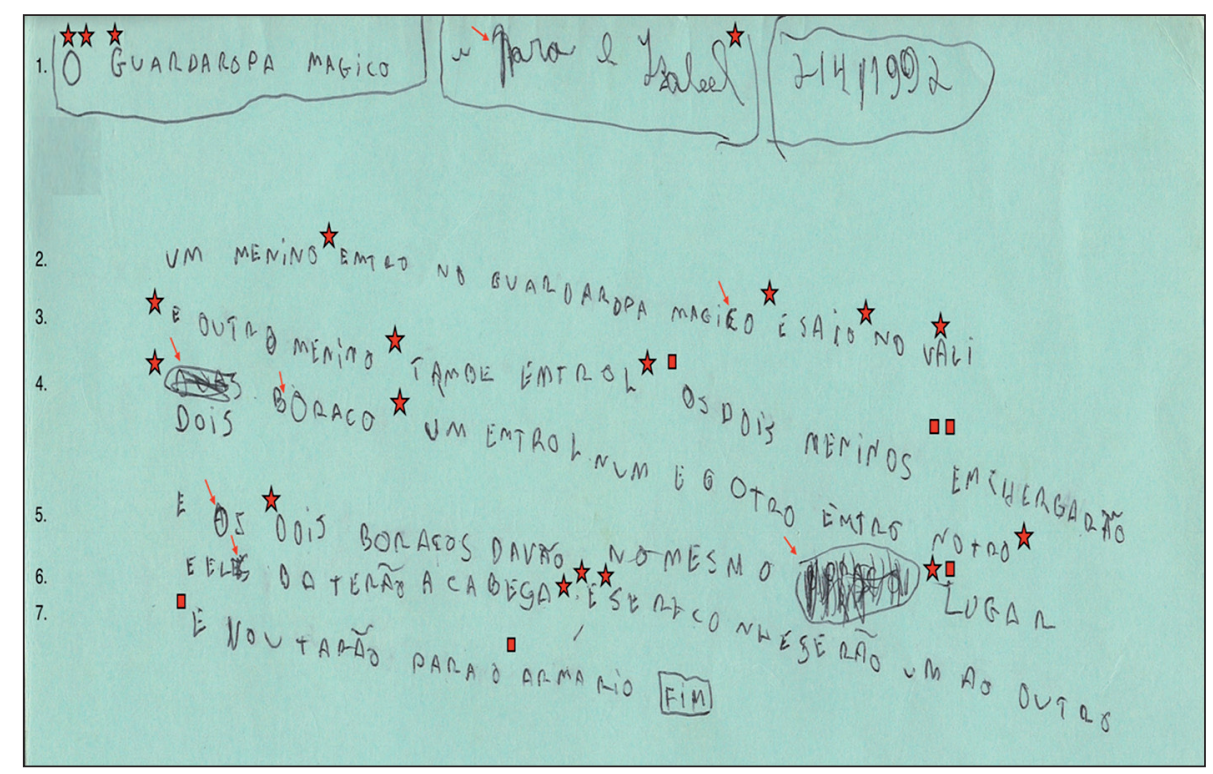

Source: School Manuscript Laboratory.

We have chosen to present the school manuscript "The Magic Closet" in its finished form, as it was handed to the teacher by the schoolchildren. The 19 stars indicate the tension points in the ongoing manuscript, whose TOs were recognized by Isabel (in charge of writing). The 6 squares indicate places where Nara (in charge of dictating the story) recognized a $\mathrm{TO}$, while the arrows indicate the 7 written erasures made in the manuscript, enabling the reader to see that not all the oral erasures resulting from the identification of textual objects led to written erasures, or vice-versa. The

23 Literal transcript (Portuguese):

1. O guarda-roupa mágico Nara e Isabel 2/4/1992

2. Um menino entrou no guarda-roupa mágico e saiu no vale

3. e outro menino também entrou. Os dois meninos enxergaram

4. is duas dois buracos. Um entrou num e o outro entrou no outro.

5. E os dois buracos davam no mesmo buraeo-lugar.

6. E eles bateram a cabeça e se reconheceram um ao outro.

7. E voltaram para o armário. FIM

Literal transcript (English):

1. The magic wardrobe Nara and Isabel 2/4/1992

2. A boy entered the magical wardrobe and came out in the valley

3. and another boy also entered. The two boys saw

4. is [duas] Fwo [dois] two holes. One went in one and the other went in the other.

5. The two holesled to the same place.

6. And they bumped heads and recognized each other.

7. And they returned to the closet. END 
use of stars and squares to identify these points helps us evaluate how productive, or not, the collaborative interaction was, i.e., the absence of tension points means that no metalinguistic reflection occurred during the writing process. In other words, the number of occurrences of oral erasures may serve as a measure of the productivity of the interactive situation, insofar as they indicate the tension points that were accompanied by metalinguistic operations.

Among these 25 tension points we will analyze the one related to the written erasure made at the beginning of line 4 . There is a substitution erasure at this point. The word "two / duas" was erased and substituted for "dois," written right below it, in line with the gender (in Portuguese) of the noun "holes / buracos":

3. [...] The two boys saw

4. [duas] [dois] two holes

Based on its position on the sheet, it can be inferred that the erasure was made at some point during the inscribing and linearization of the story, characterizing it as a "reading variation" (LEBRAVE, 1983). However, it is impossible to determine at what moment the erasure occurred. Without consistent evidence, stating that it was made right after "hole" was written would be mere speculation. One may also assume that the choice between "dois" and "duas" has to do with the concordance of gender and number which is required, in Portuguese, by the masculine plural noun "buracos." And also that the written erasure indicates the pupil pondered about this aspect when making it. But this remains a supposition, an attribution to the writer of an intention that cannot be verified from the manuscript. Despite the presence of the written erasures, the finished manuscript does not tell us what the writer was actually thinking when making them. Nor is it possible to know when the erasure occurred or what preceded its occurrence. What is stated regarding the writing process, based on the presence of written erasures on a finished manuscript, reflects the researcher's interpretive and subjective bias. Intentions are often attributed to the writer that cannot be verified or proven.

In the case of this written erasure, there is nothing but the identification of the substitution of "duas" by "dois." That is, this written erasure suggests only a problem of concordance between the number and the gender of the word "buraco" in its plural form. To obtain evidence of what really motivated this erasure, one would have to analyze the moment when it occurred.

DT_ $8^{\text {th }}$ process (manuscript “The Magic Closet”), 10:40 - 12:12.

135. NARA: Yes. But let me tell you now. (Retelling the story.) There was... A boy found a cave. The first boy got in. The second one too...

136. ISABEL*: (While Nara speaks) No. Just a moment. 
137. NARA: You know why? Because it had two entrances the cave. (Moving her hands in circles to indicate the entrances to the cave.)

138. ISABEL*: OK. So let's do it this way. The two boys... dah... ahh... saw a cave. Andone...

139. NARA: ...with two / com duas... with two holes / com dois buracos.

140. ISABEL*: Yes. With two doors / duas portas.

141. NARA: (Laughing because Isabel said 'door'.) There's a door?

142. ISABEL*: (Also laughing.) With two holes. And one got in one and the other in the other.

143. NARA: Yes.

144. ISABEL*: OK?! Then, look!

145. NARA: Yes. But they led to the same place, OK?

146. ISABEL*: Let's see. Yesss... (Looking at the sheet.) the two boys... (Speaking and inscribing 'the two boys'.) the... two [OS DOIS] ...boys... [MENINOS] boys... boys. And what was it again? The two boys... saw.

147. NARA: (Emphatically) Got in!

148. ISABEL*: No. Saw a door... tw... two doors... (Nara is laughing) one got in one and the other in the other.

149. NARA: (Laughing.) No. Two doors, no! A cave has a door?

150. ISABEL*: (Simultaneously, as Nara speaks) What is it? (After Nara speaks) Oh yes. Two holes. The boys saw... (Inscribing 'saw / enxergaram' at the end of line 3.) en...xer...ga...ram... [EMCHERGARÃO] ...saw... (Looking at Nara, smiling, and speaking in jest.) Two doors.

151. NARA: Not doors! Hole.

152. ISABEL: No. Doors. Two. Tw... o (Speaking and writing [DU] at the beginning of line 4.) doors (Writing [AS])... holes. Two doo... ho (Speaking and inscribing $[\mathrm{BO}]) \ldots$

153. NARA: ...ra.

154. ISABEL: (Speaking playfully.) Do...ors. (Showing in the manuscript that she wrote [BO] to start the word "hole / buraco," but still teasing Nara, making believe she is writing "doors") Look, por.... (Inscribing [RA]).

155. NARA: (While Isabel is speaking) ...bo...ra... Bora... (Isabel writing "CO”) ...co. (After "buraco" is inscribed, Nara is reading to see how it is written) Two holes?! / Duas buraco?! (Laughing).

156. ISABEL: "Two / Duas"? It is written "duas."

157. NARA: Huh?

158. ISABEL: It is written "duas."

159. NARA: (Reading.) Duas bo... ra... cos... ...two holes / duas buraco.

160. ISABEL: No. No, wait a minute. Let's write correctly, come on Nara. Two / Dois (Erasing [DUAS]) two / dois (Speaking and inscribing [DOIS]). 
The DT involving the occurrence of this tension point in the ongoing manuscript lasted 01:32 min. Its transcription, albeit long, demonstrates how the tension point emerged that led to the written erasure of "duas" by "dois," made by Isabel in turn 160 of this writing process. This written erasure resulted from oral erasures and comments pertaining to the inclusion of the syntagmas "two entrances / duas entradas," "two holes / dois buracos," and "two doors / duas portas."

Beginning in turn 135, Nara once again takes up the term "cave," first enunciated at the beginning of their "joint creation" of the story (turn 38). To justify why the two characters entered the same cave she says, in turn 137, "You know why? Because the cave had two entrances." What we have here is exactly the emergence of the tension point between the two girls regarding what should be written. In turn 139, Nara herself substitutes "two entrances" for "two holes" and Isabel, in 140, substitutes "entrances / entradas" and "holes / buracos" for "doors / portas." But the only thing recorded in the manuscript is "duas-dois buracos." All the other elements ("cave," "entrances," "doors"), which are responsible for the written erasure, are absent from the manuscript.

The written erasure indicates that there was tension at that point, but does not reveal what it was. Moreover, it is not possible to know what metalinguistic reflections were made by one or the other child when they substituted one word for another.

Between turns 141 and 160 in the DT, we can observe that Nara and Isabel had a confrontation over "two holes" and "two doors." The semantic relationship among the elements of the ongoing story that is being narrated and its textual alignment impose the need to choose a term related to "cave," causing Nara to select "two doors" as the TO, preventing it from being written into the story. What is of interest to us is the pupil's metalinguistic reflection to prevent "door" from being written. Nara uses the semantic correlation between "cave" and "door" to question and at the same time prevent the word "door" from being written, uttering twice: "does a cave have doors?" (turns 141 and 149). Her questioning may be considered a comment, whose argument expresses the need for textual-semantic coherence between "cave" and "hole." In other words, one cannot write "door" because a "cave" does not have a "door."

Nara uses this argument, which establishes a relationship of non-meaning between the terms "cave" and "door," to reject the latter, thereby preserving the word "hole" and ensuring this is the word to be written, which is what happened.

Analysis of the written erasure, based solely on the manuscript, misleads the researcher. It induces him to suppose that the only problem the writer faced stems from the choice between "duas" or "dois" to go with "buracos." The manuscript shows no evidence of what really took place, it contains no mark related to the fact that "duas" was written due to the feminine gender of "door / porta," which competed with the terms "entrance" and "hole." In addition, "cave / caverna," the word responsible for Nara's semantic-textual reflection (turns 141 and 149) is also absent from the manuscript. 


\section{Conclusions}

From the standpoint of textual genetics, an oral erasure is a co-enunciative phenomenon pertaining to the process of writing a text collaboratively. In our case, this phenomenon is characterized by its triple semiotic dimension. The first dimension is oral. The dialogical and ecological conditions of face-to-face interaction, in which spontaneous verbalizations are accompanied by body language, gestures, looks, facial expressions, picking up the pen and positioning it on the paper, among other multimodal aspects, facilitates access to the way schoolchildren think about the textual objects involved in the ongoing manuscript.

Like many studies that defend a socio-constructivist didactic approach based on Vygotsky's ideas, the need to dialogue in order to write collaboratively offers schoolchildren the opportunity to justify, explain, affirm, deny, and exemplify why their suggestions are suitable for what should or should not be written. However, our interpretation, which is based on an enunciative approach to text creation and to the writing process in real time, underscores the writer's relationship with the ongoing manuscript.

The second dimension of the semiotic nature of this condition of text production stems from the methodology itself, i.e., video recording the writing process and recording the ongoing manuscript; in other words, the synchronization between what is spoken to be written and what is in fact written and arranged sequentially. And lastly, the third dimension is the manuscript itself, the result of this writing process. The interface that links these three dimensions (oral, visual and written) characterizes our object of study, and this material is essential for us to identify precisely that which cannot be observed when only the final configuration of the manuscript or the record of pauses is available.

The association that we propose between these semiotic dimensions, which clearly connects the face-to-face dialogue, the manuscript being written by two schoolchildren, and its final configuration, is what enables us to argue that the oral erasure discussed in this paper provides a revealing notion about the text creation of these schoolchildren. By identifying the tension points based on these pupils' recognition of words as textual objects and on their comments, we were able to observe how students think while they are writing. Because they present certain linguistic-enunciative structures with different argumentative weights, the effect of the aforementioned comments is to erase, insert or alter these textual objects to be written or already written and arranged in sequence.

As an example, in the process that generated the "Gluttonous Queen" manuscript, we may assume that if Nara were writing the story by herself, she might have written what she said: "Dai a rainha falava... / Then the queen was saying...," or it might have been "Daí um dia com ' $b$ '... / Then one day with 'b'...". Similarly, Isabel might have written exactly what Nara dictated, if Isabel herself had not, at this point, perceived a difference between the meaning of "abcde" and "alphabetical 
order." There would have been no metalinguistic reflection about the chosen TO in either of these situations ${ }^{24}$.

Our working hypothesis is that the paired writing of a single text favors the spontaneous emergence of metalinguistic and metatextual reflections. The intersubjective nature of dyadic writing becomes more apparent when a speaker observes the differences in the way his interlocutor thinks and writes. The speaker must present arguments to "persuade" the other to write x or y. These arguments may contain important metalinguistic reflections and, at the same time, indicate explicitly what the speaker is thinking when proposing alterations of what has already been or is about to be written.

Based on oral erasures pertaining to the choice of words we can identify:

1. The moment when these terms were brought up and triggered tension points between the interlocutors while writing the manuscript.

2. How the intersubjective difference between them may give rise to comments regarding these words.

3. How their semantic and textual comments reveal what they think about the manuscript in progress.

The above examples of Isabel and Nara's comments revealed a strong concern about the meaning of the words to be written. Their comments indicated metalinguistic and metatextual reflections about the textual objects and their interrelationship with the narrative content. In the process of writing "The Three Todinhos and the Flavor Lady", the comment of semantic value related to the word "solitary" (solitária) had the effect of a substitutive erasure, preventing its inclusion in the story, in favor of writing and inserting in sequence the word "sad" (triste). In the second example, when describing the diet of the gluttonous queen, Isabel explains the concept of "alphabetical order," thus preventing the inclusion of "abcde." Nara, in the process of writing the story "The Magic Closet", correlates three terms, "entrance" (entrada), "door" (porta) and "hole" (buraco), using as argument the absence of semantic contiguity between "cave" and "door."

In addition to the relevance of the aforementioned oral erasure in mapping text creation, we believe that, from the didactic point of view, its emergence may also be seen as a means to observe the way schoolchildren learn. The identification of the recognized textual objects and the comments prompted by this recognition seem to reflect the teaching content provided by the teacher, the way in which pupils assimilate it, and how they relate it to the manuscript in progress.

24 The absence of metatextual or metalinguistic reflection would be a characteristic that Bereiter and Scardamalia (1987) named as Telling Knowledge Strategy. 
The aforementioned oral erasures would also indicate the productiveness of the interaction between the pair of schoolchildren. The large number of oral erasures and the different types of comments they elicit can be considered a reliable means to ascertain the quality of the interaction between the pupils and the differences in their linguistic knowledge and textual skills. They could also be seen as a relevant means to diagnose student learning, suggesting which contents could be given greater or lesser emphasis by the teacher in the early education of these schoolchildren as text producers.

CALIL, E. O sentido das palavras e como eles se relacionam com o texto em curso: estudo sobre comentários semânticos feitos por uma díade de alunas de 7 anos de idade. Alfa, v.60, n.3, p.537-561, 2016.

- RESUMO: Este estudo tem por objetivo analisar os comentários semânticos feitos por uma díade de alunas recém-alfabetizadas (6 a 8 anos), durante processos de escritura em tempo real. Filiado ao campo de estudos proposto pela Genética Textual, a partir de uma abordagem enunciativa, tratamos como unidade de análise o Texto Dialogal (TD) estabelecido na interação face-a-face, respeitando sua dimensão multimodal (gestos, expressões, movimentos corporais) e a fala espontânea e co-enunciativa dos alunos em dupla. O TD se constitui pelo reconhecimento por um dos locutores de objetos textuais $(O T)$ e os comentários relacionados a esses objetos. A relação entre os OT reconhecidos e os comentários semânticos é definida como um tipo de Rasura Oral Comentada (ROC). Nossa análise tomou por base um corpus constituído pelo registro filmico de 16 processos de escritura de histórias inventadas por uma mesma diade de alunas. Discutimos a ocorrência deste tipo de ROC em 3 processos de escritura. Nossos resultados indicam que os comentários semânticos dirigidos aos OT visavam ao estabelecimento da unidade textual, indicando o modo como as alunas estavam pensando sobre este problema durante o manuscrito em curso. A relação entre os OT e os comentários semânticos proferidos mapeou a gênese e o processo de criação textual. Além disso, as ROC semânticas evidenciam conhecimentos linguísticos e textuais dos alunos que não são possíveis de se identificar no manuscrito acabado.

- PALAVRAS-CHAVE: Sala de aula. Produção textual. Diálogo. Escrita. Autoria. Manuscrito. Rasura.

\section{REFERENCES}

ALCORTA, M. Utilisation du brouillon et développement des capacités d'écrit. Revue Française de Pédagogie, Paris, v.137, p.95-103, 2001.

APOTHÉLOZ, D. Progressive de texte dans les redactions conversationnelles: les techniques de la reformulation dans la fabrication du texte. In: MONDADA, 
L.; BOUCHARD, R. (Éd.). Les processus de la rédaction collaborative. Paris: L'Harmattan, 2005. p.165-199.

APOTHÉLOZ, D. Usages de l'autonymie dans les redactions conversationnelles. In: LOPEZ-MUÑOZ, J. M.; MARNETTE, S.; ROSIER, L. (Éd.). Le Discours rapport dans tous ses états. Paris: L'Harmattan, 2004. p. 335-349.

APOTHÉLOZ, D. Référer sans expression référentielle: gestion de la référence et opérations de reformulation dans des séquences métalinguistiques produites dans une tâche de rédaction conversationnelle. In: NÉMETH, E. T. (Éd.). Pragmatics in 2000: selected papers from the 7 th International Pragmatics Conference. Antwerp: International Pragmatics Association, 2001. p. 30-38. v. 2.

BEREITER, C.; SCARDAMALIA, M. The psychology of written composition. Hilsdale: Lawrence Erlbaum Associates, 1987.

BERNINGER, V. et al. Developmental skills related to writing and reading acquisition in the intermediate grades: Shared and unique variance. Reading and Writing: An Interdisciplinary Journal, Dordrecht, v.6, p.161-196, 1994.

BIASI, P.-M. de. Qu'est-ce qu'une rature? In: ROUGÉ, B. (Éd.). Ratures et repentirs. Pau: Publications de l'Université de Pau, 1996. p.17-48.

BORÉ, C. Le brouillon, introuvable objet d'étude? Pratiques: Linguistiques, Littérature, Didactique, [S.1.], n.105-106, p.23-49, 2000.

BOUCHARD, R. Les pratiques métalangagières en situation fonctionnelle (production collective de texte écrit. Linx, Nanterre, v.37, p.97-106, 1997.

BOUCHARD, R.; GAULMYN, M.-M. de. Médiation verbale et processus rédactionnel: parler pour écrire ensemble. In: GROSSEN, M.; PY, B. (Éd.). Pratiques sociales et médiations symboliques. Berne: Peter Lang, 1997. p. 153-173.

BOUCHARD, R.; MONDADA, L. (Éd.). Les processus de la rédaction collaborative. Paris: L'Harmattan, 2005.

CALIL, E. Rasura oral comentada: definição, funcionamento e tipos em processos de escritura a dois. In: SILVA, C.; DEL RE, A.; CAVALCANTE, M. (Ed.). A criança na/com a linguagem: saberes em contraponto. Porto Alegre: Ed. da UFRGS, [2017]. No prelo.

CALIL, E. Dialogisme, hasard et rapture oraleAnalysegénétique de la création d un texte par des élèves de 6 ans. In: BORÉ, C.; CALIL, E. (Éd.). L'école, l'écriture et la création: études franco-brésiliennes. Louvain-la-neuve: L'Harmattan-Academia, 2013. p.157-188. 
CALIL, E. La rature orale en processos d'écriture em acte: lieu de tension et production du sens. In: LORDA, C. (Ed.). Polifonía e intertextualidad en el diálogo. Madrid: Arco Libros, 2012a. p. 215-230.

CALIL, E. Dialogues between two pupils during the process of writing a fictional story Verbal erasures and their forms of representation. In: COOREN, F.; LÉTOURNEAU, A. (Ed.). (Re)presentations and dialogue. Amsterdam: John Benjamins Publishing Company, 2012b. p. 325-341.

CALIL, E. Autoria: a criança e a escrita de histórias inventadas. Londrina: Ed. da UEL, 2009.

CALIL, E. Escutar o invisível: escritura \& poesia na sala de aula. São Paulo: Ed. da UNESP, 2008.

CALIL, E. Processus de création et ratures: analyses d'unprocessus d'écriture dans um texte rédige par deux écoliers. Langages \& Société, [S.1.], v.103, p.31-55, 2003.

CALIL, E. A criança e a rasura na prática de textualização de história inventada. Letras de Hoje, Porto Alegre, v.33, n.2, p.13-21, 1998.

CALIL, E.; FELIPETO, C. Paired fiction writing: the dialogal text as a structure that triggers "verbal erasure". In: MELLO, H.; PETTORINO, M.; RASO, T. (Ed.). GSCP International Conference: Speech and Corpora. Firenze: Firenze University Press, 2012. p.318-322.

CAMPS, A. et al. Dialogue d'élèves et production textuelle. Activité métalinguistique pendant le processus de production d'un texte argumentatif. Recherches, v.27, p.133156, 1997.

CRINON, J. The dynamics of writing and peer review at primary school. Journal of Writing Research, Antwerpen, v.4, n.2, p.121-154, 2012.

DAIUTE, C.; DALTON, B. Collaboration between children learning to write: can novices be masters? Cognition and Instruction, Mahwah, v.10, p.281-333, 1993.

DALE, H. Collaborative writing interactions in one ninth-grade classroom. The Journal of Education Research, [S.1.], v.87, n.6, p.334-344, 1994.

DAVID, J. Typologie des procedures metagraphiques produites en dyades entre 5 et 8 ans. L'exemple de la morphologie du nombre. In: GAULMYN, M. M. de.; BOUCHARD, R.; RABATEL, A. (Éd.). Le processus rédactionnel: ecrire à plusieurs voix. Paris: L'Harmattan, 2001. p.281-292.

GAULMYN, M.-M. de. Recherche lyonnaise sur la rédaction conversationnelle. In: BOUCHARD, R.; GAULMYN, M.-M. de.; RABATEL, A. (Éd.). Le processus rédactionnel: écrire à plusieurs voix. Paris: L'Harmattan, 2001. p. 11-48. 
GAULMYN, M.-M. de. La rédation conversacionalle: parler pour écrire. Le Français Aujourd'hui, Sevres, v.108, p.73-81, 1994.

DOQUET, Cl. L'écriture débutant: pratiques scripturales à l'école élémentaire. Rennes: Presses Universitaires de Rennes, 2011.

DOQUET, Cl. Approche contextuelle du sens et activités lexicologiques à l'école élémentaire. In: GROSSMAN, F.; PLANE, S. (Éd.). Lexique et production verbale: vers une meilleure intégration des apprentissages lexicaux. Lille: Presses Universitaires du Septentrion, 2008. p. 125-140.

FABRE, Cl. Réécrire à l'école et au collège: da l'analyse des brouillons à l'écriture accompagnée. Issy-les Moulineaux: ESF Éditeur, 2002.

FABRE, Cl. Les brouillons d'écoliers ou l'entrée dans l'écriture. Grenoble: Ceditel, 1990 .

FELIPETO, C. Rasura e equívoco no processo de escritura na sala de aula. Londrina: Ed. da UEL, 2008.

GAULMYN, M.-M. de.; BOUCHARD, R.; RABATEL, Al. (Éd.). Le processus rédactionnel: écrire à plusieurs voix. Paris: L'Harmattan, 2001.

GRÉSILLON, A. Eléments de critique génétique: lire les manuscrits modernes. Paris: Presses Universitaires de France, 1994.

HAYES, J.; FLOWER, L. Identifying the organization of the writing processes. In: GREGG, L. W.; E. STEINBERG, R. (Ed.). Cognitive processes in writing. Hillsdale: Lawrence Erlbaum Associates, 1980. p.3-30.

LEBRAVE, J. L. Lecture et analyse des brouillons. Langages, [S.1.], v.17, n.69, p. 11-23, 1983.

MILIAN, M. Reformulation: a means of constructing knowledge in shared writing. Educational Studies in Language and Literature, [S.1.], v.5, p.335-351, 2005.

MONDADA, L. Verbalisation de l'espace et fabrication du savoir: approche linguistique de la construction des objets de discours. Lausanne: Université de Lausanne, 1994.

MORIN, M.-Fr. Declared Knowledge of beginning writes. Educational Studies in Language and Literature, [S.1.], v.5, p.385-401, 2005.

PENLOUP, M.-Cl. La rapture n'est pas un rate: plaidoyer pour le brouillon. Rouen: MAFPEN, 1994.

PLANE, S. Singularités et constantes de la production d'écrit - l'écriture comme traitement de contraintes. In: LAFFONT-TERRANOVA, J.; COLIN, D. (Ed.). 
Didactique de l'écrit: la construction des savoirs et le sujet-écrivant. Namur : Presses Universitaires de Namur, 2006. p.33-54.

ROJAS-DRUMMOND, S. M.; ALBARRAN, C. D.; LITTLETON, K. Collaboration, creativity and the co-construction of oral and written texts. Thinking Skills and Creativity, [S.1.], v.3, n.3, p.177-191, 2008.

STORCH, N. Are two heads better than one? Pair work and grammatical accuracy. System, [S.1.], v.27, n.3, p.363-374, 1999.

SWAIN, M.; LAPKIN, S. Talking it through: two French immersion learners' response to reformulation International. Journal of Educational Research, Washington, v.37, p.285-304, 2002.

VASS, E. Exploring processes of collaborative creativity: the role of emotions in children's joint creative writing. Journal of Thinking Skills and Creativity, [S.l.], v.2, p.107-117, 2007.

Received in March 2016

Approved in September 2016 